\title{
Investigation of Some Biomatoric and Physiological Effects of People's Plays in Individuals in Regenarian Folk Player Exercises (Van Sample)
}

\author{
Kemal Sargin ${ }^{1}$, Muzaffer Selçuk ${ }^{1}$ \\ ${ }^{1}$ Van Yüzüncü Y1l University, Pyhsical Education and Sport Department, Turkey \\ Correspondence: Muzaffer Selçuk, Van Yüzüncü Y1l University, Pyhsical Education and sport department, Turkey.
}

Received: April 9, 2018

Accepted: April 22, 2018

Online Published: April 23, 2018

doi:10.11114/jets.v6i6.3185

URL: https://doi.org/10.11114/jets.v6i6.3185

\begin{abstract}
This study has been performed on 44 volunteers all of whom are students in Yüzüncü Y1l University and participating in the university's folk dances activities. A twelve week program was carried out. The data was obtained in a relaxed mood before the programme, on the first day after the exercise, and at the end of the programme it was obtained first in relaxed mood and then after the exercise. Before starting the program while The level of LDH was observed as being $321,818 \pm$ in relaxed mood, it was found to be $265,136 \pm(\mathrm{p}<0.001)$ after the program in relaxed mood. The difference is considered to be meaningful. Before the program, in relaxed mood, while the level of CK was found to be $169.772 \pm$ after the program, in relaxed mood again, it was found as being $113.227 \pm(\mathrm{p}<0.001)$ This difference has been considered to be important. The level of HDL, before the programme in relaxed mood, was observed to be $44,690 \pm$ after the programme in relaxed mood it was observed having risen to $62,490 \pm(\mathrm{p}<0.001)$. The difference has been considered important. While LDL level, before the programme in relaxed mood, was observed to be $85,426 \pm$, after the programme in relaxed mood it was found to be $67,299 \pm(\mathrm{p}<0.001)$ The difference has been considered important.
\end{abstract}

Keywords: folk dance, exercise, lipoprotein, creatine kinase, lactate dehidrogenase

\section{Intrioduction}

It is a problem to make a full description of folklore while it is used regularly in daily conversations. The folklore term is clearly composed of words of folk and lore. Folk "is a group of people, while the word of "lore" involves everything that people have. When folklore is translated into Turkish as a term, it means "science of people" (Ay, 1999).

Folklore was first introduced by William Thoms, an archaeologist and writer, in England in 1846. Thoms, in one of his articles published, described the products, that were deemed as the folk literature, folk customs and products until that day, as pieces of folklore. This perspective soon became influential all over the world, especially in European countries, and folklore was regarded as an independent field of science; and folklore institutions were established to collect and disseminate materials about folklore of each country. Folklore also includes folk dances, folk songs, medicine and narratives. Much of our folklore works in our country are focused on two branches. These are folk dances and folk songs. (Ay, 1999).

"Oyun" (dance) is a word in Turkish language. It is the oldest and universal in terms of language and expression. Oyun (dance) is the expression of emotion and thought through motion. This expression is closely related to the society in which it is experienced. Oyun (dance) is formed by the existence of human beings before civilizations. In daily life, hunting, life, struggle, death, movement, rhythm is described by dance, than by the combination of music instruments. Dance, which is synonymous of the "Oyun", is performed by the person or persons who do the body movements in company with music. The music has been following dance for centuries and has taken its measurements from it. Our folk dances are centred by humenbeings, and our dances also tell about people and their experiences. (Ay, 1999).

As for rhythm which is a basic category both in sports education and movement education, rhythm, as a general phenomenon, exists in cosmic phenomenon and in human and non-human events. Explanation of this phenomenon involving all entities goes from metaphysical interpretations to biomechanical explanations. Rhythm in sports movements is a motoristic coordination and functional integration of the physical, spiritual and mental processes and forces that make up the human being. (Orhun 1998; Yoncalık, 2004). At the rhythm, the quality and quantity of human's motion performance appear together. The rhythm in human movements is the expression of "I" as the expression of the body. The movement's rhythm reflects aesthetic values and gestures such as nobility, economy, organic integrity, 
structure, time and space dimension, emphasis, dynamics and fluency. All these features and qualities make it more meaningful when it is done in company with music. (Orhun, 1998).

Sports is a symbolic image of the dance and agonal movements (competition) and an manifestation of the cultural performance. Motion and dance are embodied and structured in sport. The natural impulse of the human being becomes technical in dance and sport and transformed into art (Orhun, 1998). In this sense, we can not differentiate the Folk Dances from other forms of sport and activities. Because it is a long-lasting and some time intensifying way of charging, it often comes up as an activity that needs support from the aerobic system. The development of conditioning skills in Folk Dances will greatly facilitate technical applications. For successfully performance of dance, coordination, flexibility, strength, durability, as well as the balance and rhythm of the dance is of great importance. Despite its complicated structure, it is observed that sport is done for the following purposes in the modern world. Competitions and performance sports, fitness sports referring to sports done or the purpose of healthy life are sports that are done for having good time and recreation. Folk dances also comply with the qualifications described above as an application. Exercise is a very important factor for a healthy life (Selçuk, 2003). Exercise creates physiological changes in the body, especially in skeletal and cardiac respiratory system. The effects of exercise are lost in several weeks after training, depending on the frequency of exercise-related changes, the duration and, in particular, the intensity of the exercises. The effects of exercise can be maintained by loads done once or twice a week. (Fox, 1988). Regular exercises increase maximal oxygen capacity. Regular exercises also increase the strength, endurance, coordination and flexibility of the individual's biomaterials. Increasing biomotical properties increase the physical performance of sportive activities, causing them to continue to function more effectively in their daily lives. (Aldemir, 1999). Nowadays, it is important to clearly demonstrate the benefits of regular exercises for human health.

This study was conducted to determine the effects of folk dance exercises on the biomotoric and physiological characteristics of sedentaries and individuals regularly participating in folk dances.

\section{Materials and Method}

\subsection{Research Sample}

44 students of Yüzüncü Y1l University from 17-24 age group (22 female, 22 male) were voluntarily participated in this research. All the subjects were composed of students who studied in various departments of Yüzüncü Yıl University. Sedanters were selected from individuals who did not do any sports, while the other group was from individuals who did Folk Dances.

\subsection{Creating Workgroups}

In the groups, 44 subjects were used, 22 of which were female and 22 were male. Subjects were girls and boys between the ages of 17-24 who were volunteers and had no health problems. The study lasted for 12 weeks, the groups were regularly practiced folk dances in various intensity for 2 hours in a day and 3 days a week. The folk dances were conducted in İlyas Türetken indoor sport hall, belonging to Department of Health, Sports and Culture in Yüzüncü Yll University for 2 hours in a day and three days a week. Tests and measurements were made at Yüzüncü Yıl University Ilyas Türetken Indoor Sports Hall and outdoor area. Blood analyses were done at the Biochemistry Laboratory of Hayat Hospital.

\subsection{Tools Used}

Plastic injectors for bleeding, EDTA blood storage tubes, soil field for Cooper Test, tape measure and Jemis Spotwatch brand stopwatch for 30 meters run; floor of the Sports all for standing and long jump; gym mattresses for the shuttle test are used. The tests were performed in the indoor sports hall of İlyas Türetken.

\section{Method}

Experimental method was used in our research. The study group consisted of 22 students ( 11 girls, 11 boys) who did not start to folk dances or long-term exercises and 22 students (11 girls, 11 boys) who studied in various departments of Yüzüncü Yıl University without active sports life. The blood samples of the experiment group were taken at rest at the beginning and end of the study and sitting and hungry after 60 minutes of work. The blood samples of the control group were taken at the same time as the experimental group and hung open.

\subsection{Blood Samples}

Before the commence of 12 weeks of work, to determine the levels of Lactic Dehydrogenise (LDH), Cretin Kinas (CK), Cholesterol, Triglyceride, High Density Lipoprotein (HDL), Low Density Lipoprotein (LDL), and Very Low Density Lipoprotein (VLDL) levels in the bloods of subject group and control group, mean seven cc blood samples were taken with a tourniquet-sterilized plastic injector, when sitting, applied to the their arms by three healthcare personnel. Blood samples were taken with previously prepared anticoagulant EDTA (Ethylenediaminetetraacetic acid) tubes and then analyses were carried out in the Private Life Hospital laboratory with Hitachi Automatic Analyzer. 


\subsection{Performance Tests}

Cooper Test: The Cooper capitalize is a test that requires the athlete to run the longest possible distance in twelwe minutes. With this test, Max VO2 is determined indirectly (Baumgartner et al., 2003). In this test, the most important criterion of aerobic power, Max VO2, is calculated indirectly through the formula. Participants were run/walked in groups and their distances were measured, and for each participant, a person who was constantly watching the distance he was running and could be on his/her spot when the stop command came in was assigned. The distance from the test is converted to land mile and put into form. The amount of oxygen used per kilogram in this way is calculated by adapting to the following formula.

Max. VO2 $=\left(\mathrm{ml} \bullet \mathrm{kg}^{\bullet 1} \cdot \min \bullet^{1}\right)=($ distance -0.3138$) \div 0.0278=$ Result

The result after this calculation shows the aerobic capacity or in other words the endurance characteristic.

Standing long jump test: For standing long jump test, the subjects were standing adjacent to their feet and the toes would be behind the jump line, and they jumped forward as far as possible by bending their knees and, shaking both arms backwards. The best value was recorded from three trials. Two minutes of rest were given between each experiments (Koç et al., 2011).

Flexibility Test: A sit and reach test was used to measure flexibility. Participants were seated and their bare feet were laid as flat on the test bench. The body leaned forward, stretched forward as far as the knees would be in front of the hand of the body without twisting, pushing the ruler slowly forward. At the farthest point, one-two seconds was expected to wait without stretching forward or backward. The test was repeated twice and the highest value was recorded (Saygin et al., 2005)

Shuttle test: It's a test that measures the durability of your abdominal muscles. Participants were asked to lie in flat position, with bent knees at 90 degrees, their soles on the floor, and the hands tied behind their heads. The test was started with the start command after the subjects feet were fixed by the test team. With the start command of the person holding the chronometer, every correct movement of subject was recorded by a person. (Diker and Müniroğlu, 2016).

30 meters run test: The measurement was made with a Newtest Finland brand photocell stopwatch set between zero and $30 \mathrm{~m}$ on the running track determined in the hall; and the athlete's running time of this distance was measured, the best of three attempts was recorded. Two minutes of rest were given between each trial (Taşkın et al., 2015).

Statistical Analysis: In the analysis of the data, SPSS statistical package program was used. Percent frequency, arithmetic mean, standard deviations (standard errors) of the obtained data were calculated. The "paired t" test was used to determine the differences between the groups.

\section{Findings}

In this section, the data about the personal information and exercise status of the students participating in the research were resolved and the findings obtained and interpretations based on these findings were presented.

Table 1. Demographic Information of the Subject Group and Control Group Attending to the Research

\begin{tabular}{|c|c|c|c|c|c|c|}
\hline Personal Information & Subject Group & $\begin{array}{l}\text { Frequency } \\
\text { (F) }\end{array}$ & Percentage (\%) & Control Group & $\begin{array}{l}\text { Frequency } \\
\text { (F) }\end{array}$ & Percentage (\%) \\
\hline & Female & 11 & 50 & Female & 11 & 50 \\
\hline \multirow[t]{4}{*}{ Gender } & Male & 11 & 50 & Male & 11 & 50 \\
\hline & Total & 22 & 100 & Total & 22 & 100 \\
\hline & $17-21$ & 18 & 81,81 & $17-21$ & 19 & 83,36 \\
\hline & $21-24$ & 4 & 18,18 & $21-24$ & 3 & 13,63 \\
\hline \multirow[t]{3}{*}{ Age } & Total & 22 & 100 & Total & 22 & 100 \\
\hline & $55-65$ & 12 & 54,54 & $55-65$ & 9 & 40,90 \\
\hline & $65-75$ & 10 & 45,45 & $65-75$ & 13 & 59,09 \\
\hline \multirow[t]{2}{*}{ Weight (kg) } & Total & 22 & 100 & Total & 22 & 100 \\
\hline & Don't do Sport & 19 & 86,36 & Don't do Sport & 21 & 95,45 \\
\hline \multirow[t]{3}{*}{ Sedentary Status } & $1-3(\mathrm{y} 1 \mathrm{l})$ & 3 & 13,63 & $1-3(\mathrm{y} 1 \mathrm{l})$ & 1 & 4,54 \\
\hline & Total & 22 & 100 & Total & 22 & 100 \\
\hline & Don't smoke & 8 & 36,36 & Don't smoke & 7 & 31,81 \\
\hline \multirow[t]{3}{*}{ Smoking Status } & $1-3(\mathrm{y} 1 \mathrm{l})$ & 11 & 50 & $1-3(\mathrm{y} 1 \mathrm{l})$ & 10 & 45,45 \\
\hline & $3-5(\mathrm{y} 1 \mathrm{l})$ & 3 & 13,63 & $3-5(\mathrm{y} 1 \mathrm{l})$ & 5 & 22,72 \\
\hline & Total & 22 & 100 & Total & 22 & 100 \\
\hline \multirow[t]{4}{*}{ Folk Dance Status } & Never dance & 10 & 45,45 & Never dance & 18 & 81,81 \\
\hline & $1-3(\mathrm{y} 1 \mathrm{l})$ & 9 & 40,90 & $1-3(\mathrm{y} 1 \mathrm{l})$ & 2 & 9,09 \\
\hline & $3-5(\mathrm{y} 1 \mathrm{l})$ & 3 & 13,63 & $3-5(\mathrm{y} 1 \mathrm{l})$ & 2 & 9,09 \\
\hline & Total & 22 & 100 & Total & 22 & 100 \\
\hline
\end{tabular}

Of subject group, $50 \%$ is (11 persons) male and $50 \%$ (11 persons) female, $54.54 \%$ (12 persons) is $55-65 \mathrm{~kg}$ and \% 
45.45 (10 persons) $65-75 \mathrm{~kg}, 81.81 \%$ (18 persons) are at age of $17-21$ and $18.18 \%$ (4 persons) $21-24$. Of Control group, $50 \%$ is ( 11 persons) male and $50 \%$ (11 persons) female, $54.54 \%$ (12 persons) is $55-65 \mathrm{~kg}$ and $\% 45.45$ (10 persons) $65-75 \mathrm{~kg}, 86,36 \%$ (19 persons) $17-21$ ages and 13,63\% (3 persons) $21-24$ ages.

Table 2. Pre- and Post-Work Values of the Subject Group Attending to the Research

\begin{tabular}{llllccc}
\hline Measurements & Pre / Final test & $\mathbf{N}$ & $\overline{\boldsymbol{X}}$ & Ss & Min & Max \\
\hline \multirow{2}{*}{ LDH } & Pre test & 22 & 372,136 & 72,773 & 279 & 505 \\
CK & Final test & & 290,409 & 36,703 & 201 & 350 \\
& Pre test & 22 & 203,636 & 85,180 & 76 & 368 \\
KOLESTEROL & Final test & & 120,500 & 70,134 & 44 & 310 \\
& Pre test & 22 & 147,809 & 22,789 & 107 & 194 \\
TRIGLISERID & Final test & & 126,754 & 17,781 & 90 & 160 \\
& Pre test & 22 & 88.5 & 41,426 & 43 & 223 \\
HDL & Final test & & 52,731 & 16,902 & 27,7 & 88,2 \\
& Pre test & 22 & 44,238 & 11,604 & 22,01 & 66 \\
LDL & Final test & & 61,181 & 10,974 & 44 & 83 \\
& Pre test & 22 & 85,951 & 21,378 & 50,01 & 141 \\
VLDL & Final test & & 64,950 & 18,858 & 31 & 103 \\
& Pre test & 22 & 17,157 & 6,873 & 8,6 & 34,2 \\
& Final test & & 9,826 & 2,356 & 5,54 & 14,03 \\
\hline
\end{tabular}

Table 3. Comparison of Pre and Post Exercises Values of the Subject Group Attending to the Research

\begin{tabular}{|c|c|c|c|c|c|c|}
\hline Measurements & $\mathbf{N}$ & & $\bar{z}$ & Ss & Min & Max. \\
\hline LDH1-LDH2 & & 22 & 81,727 & $64,445 * *$ & 53,154 & 110,300 \\
\hline CK 1-CK 2 & & 22 & 83,136 & $63,344 * *$ & 46,613 & 119,658 \\
\hline KOLES.1-KOLES.2 & & 22 & 22,881 & $19,086^{*}$ & 14,419 & 31,344 \\
\hline TRIG.1 -TRIG.2 & & 22 & 35,768 & $40,413 * *$ & 17,850 & 53,687 \\
\hline HDL 1-HDL 2 & & 22 & $-16,943$ & $10,685 * *$ & $-21,681$ & $-12,205$ \\
\hline LDL 1- LDL 2 & & 22 & 21,001 & $14,307 * *$ & 14,658 & 27,345 \\
\hline VLDL1- VLDL2 & & 22 & 7,330 & $6,731 * *$ & 4,345 & 10,315 \\
\hline
\end{tabular}

The values shown in Tables 2 and 3 are the mean values of the values obtained from the Folk Dancers before and after the exercises, on the beginning at the end of the training program. From these mean values, the LDH level was 372,136 \pm after exercise at the beginning of the program, but decreased to $290,409 \pm$ after exercise at the end of 12 weeks program; CK level was 203,636 \pm after exercise at the beginning of the program, but decreased to $120,500 \pm$ after exercise at the end of 12-week program; , the cholesterol level was 147,809 \pm after exercise at the beginning of program, it decreased to $126,724 \pm$ after exercise at the end of the 12-week program,; the triglyceride level was $88.50 \pm 50 \%$ after exercise at the beginning of the program and decreased to 52,731 $\pm 50 \%$ after exercise at the end of the 12-week program; HDL was 44,238 \pm at the beginning of the programme and increased to $61,181 \pm$ after the exercise at the end of the 12-week program; and the LDL level was $85.951 \pm$ initially and was decreased to $67,950 \pm$ after exercise at the end of the 12-week program; and VLDL was 17,157 \pm at the beginning and decreased to 9,826 \pm after exercise at the end of the 12-week program. LDH, CK, Cholesterol, Triglyceride, LDL and VLDL values decreased in comparison with baseline; and HDL was higher than baseline. All of these differences are statistically significant $(\mathrm{p}<0.001)$.

Table 4. Pre- and Post-Exercises Values of the Control Group Attending to the Research

\begin{tabular}{lllllcc}
\hline Measurements & Pre / Final test & $\mathbf{N}$ & $\overline{\boldsymbol{X}}$ & Ss & Min & Max \\
\hline \multirow{2}{*}{ LDH } & Pre test & 22 & $238,636 \%$ & $118,591 \%$ & 79 & 489 \\
CK & Final test & & $249,590 \%$ & $120,848 \%$ & 82 & 480 \\
& Pre test & 22 & $144,545 \%$ & $87,099 \%$ & 59 & 347 \\
\multirow{2}{*}{ KOLESTEROL } & Final test & & $149,636 \%$ & $87,004 \%$ & 59 & 352 \\
& Pre test & 22 & $157,272 \%$ & $29,274 \%$ & 102 & 215 \\
\multirow{2}{*}{ TRIGLISERID } & Final test & & $159,590 \%$ & $29,483 \%$ & 97 & 220 \\
& Pre test & 22 & $114,409 \%$ & $78,384 \%$ & 38 & 357 \\
HDL & Final test & & $108,227 \%$ & $74,081 \%$ & 44 & 368 \\
& Pre test & 22 & $55,872 \%$ & $15,454 \%$ & 33 & 89,2 \\
\multirow{2}{*}{ LDL } & Final test & & $57,572 \%$ & $14,857 \%$ & 35 & 88,04 \\
& Pre test & 22 & $73,863 \%$ & $21,979 \%$ & 45 & 123 \\
VLDL & Final test & & $75,262 \%$ & $20,059 \%$ & 41 & 122 \\
& Pre test & 22 & $16,474 \%$ & $11,088 \%$ & 5,8 & 53,2 \\
& Final test & & $17,145 \%$ & $12,515 \%$ & 5,8 & 63 \\
\hline
\end{tabular}


Table 5. Comparison of pre and post exercises values of the control group Attending to the Research

\begin{tabular}{lcclcc}
\hline Measurements & $\mathbf{N}$ & $\overline{\boldsymbol{X}}$ & Ss & Min & Max. \\
\hline LDH1-LDH2 & 22 & $-11,227 \%$ & $67,769^{* *}$ & $-41,274$ & 18,819 \\
CK 1-CK 2 & 22 & $-5,090 \%$ & $14,703 * *$ & $-11,609$ & 1,428 \\
KOLES.1-KOLES.2 & 22 & $-2,318 \%$ & $6,431^{* *}$ & $-5,170$ & 0,533 \\
TRIG.1 -TRIG.2 & 22 & $6,136 \%$ & $27,115^{* *}$ & $-5,886$ & 18,158 \\
HDL 1-HDL 2 & 22 & $-1,221 \%$ & $3,089^{* *}$ & $-2,591$ & 0,148 \\
LDL 1- LDL 2 & 22 & $-1,398 \%$ & 5,724 & $-3,936$ & 1,139 \\
VLDL1- VLDL2 & 22 & $-0,671 \%$ & $3,087 * *$ & $-2,040$ & 0,697 \\
\hline
\end{tabular}

The values shown in Tables 4 and 5 are the average values obtained from the control group before and after the study program and from the blood taken at rest. From these mean values, the LDH level was 238,636 \pm before the research program and was 249,590 \pm after the research program, The CK level was 144,545 \pm before the research program and increased to $149,636 \pm$ after the research program; cholesterol was $157,272 \pm$ before the study program and was $159,590 \pm$ after the research program; triglyceride levels were 114,409 \pm before the research program and decreased to $108,227 \pm$ after the research program; before the research program the HDL was 55,872 \pm and it increased to 57,572 \pm after the research program; and LDL level was 73,863 \pm at the beginning and was 75,262 \pm at the end of the research; and VLDL was $16,474 \pm$ at the beginning of the research and increased to $17,145 \pm 15 \%$, respectively. All of these differences are statistically significant $(\mathrm{p}<0.001)$.

Table 6. Pre and Post Motoric Test Results of the Subject Group Attending to the Research

\begin{tabular}{lllcccc}
\hline Measurements & Pre / Post test & $\mathbf{N}$ & $\overline{\boldsymbol{X}}$ & Ss & Min & Max \\
\hline \multirow{3}{*}{ VO2-max. } & Pre test & 22 & 39,902 & 11,837 & 20,94 & 250 \\
S.L.J. & Final test & & 42,132 & 14,644 & 16,92 & 61,23 \\
& Pre test & 22 & 174,00 & 49,178 & 102 & 250 \\
FLEXIBILITYY & Final test & & 177,55 & 49,354 & 108 & 254 \\
& Pre test & 22 & $30,09 \%$ & 6,596 & 21 & 44 \\
30.M RUN & Final test & & $33,36 \%$ & 7,234 & 20 & 48 \\
& Pre test & 22 & 5,83 & 1,114 & 4,56 & 8,45 \\
SHUTTLE & Final test & & 5,4 & 1,32 & 4,10 & 7,91 \\
& Pre test & 22 & 49,86 & 28,894 & 13 & 94 \\
& Final test & & 56,55 & 30,801 & 11 & 100 \\
\hline
\end{tabular}

Table 7. Comparison of Pre and Post Motoric Test Results of the Subject Group Attending to the Research

\begin{tabular}{lrllll}
\hline \multicolumn{1}{c}{ Measurements } & N & \multicolumn{1}{c}{$\boldsymbol{X}$} & \multicolumn{1}{c}{ Ss } & \multicolumn{1}{c}{ Min } & \multicolumn{1}{c}{ Max. } \\
\hline VO2max1-VO2max2 & 22 & $-2,230$ & $7,127^{* *}$ & $-5,390$ & 0,930 \\
S.L.J.1-S.L.J.2 & 22 & $-3,545$ & $1,765^{* *}$ & $-4,328$ & $-2,762$ \\
FLEX.1- FLEX.2 & 22 & $-3,272$ & $1,906^{* *}$ & $-4,118$ & $-2,247$ \\
30 M.RUN.1-30M.RUN.2 & 22 & 0,331 & $0,225^{* *}$ & -15 & -12 \\
SHUTTLE 1-SHUTTLE 2 & 22 & $-6,681$ & 3,932 & 8,425 & $-7,969$ \\
\hline
\end{tabular}

The data given in Tables 6 and 7 are statistical information on the values of the subject group before and after the test. From the motoric tests, the Cooper test was calculated at max.VO2 $39,902 \pm \mathrm{ml} \cdot \mathrm{kg} \cdot{ }^{1}$. minute ${ }^{1}{ }^{1}$ at the beginning of the work program. It was increased to max.VO2 $42,132 \pm \mathrm{ml} \cdot \mathrm{kg} \cdot{ }^{1}$. minute ${ }^{1}$ level after the 12 weeks experiment programe. In the Standing Long Jump test, $174.00 \pm \mathrm{cm}$ average value was obtained at the beginning of the study program, but this value increased to $177,55 \pm \mathrm{cm}$ after the exercises. The elasticity value was $30.09 \pm \mathrm{cm}$ at the beginning and it was $33.36 \pm$ at the end of the exercises program. As to the 30-meter running test, an average of $5.83 \pm$ seconds was obtained at the beginning of the program, and at the end of the exercises program, this initial value decreased to $5.49 \pm$ seconds. At the beginning of the 12-week exercises program, the average number of shuttles was $49.86 \pm$, while at the end of the exercises program it increased to $56.55 \pm$ shuttles. From these values, there is an increase in long jump, resilience and shuttle test results by standing at max VO2. It was also determined that there was a decrease in the duration of the 30 -meter running test results. All of these differences are statistically significant $(\mathrm{p}<0,001)$. 
Table 8. Pre- and Post- exercises Motoric Test Results of the Control Group Attending the Research

\begin{tabular}{lllllll}
\hline Measurements & Pre / Post test & $\mathbf{N}$ & $\overline{\boldsymbol{X}}$ & Ss & Min & Max \\
\hline \multirow{2}{*}{ VO2-max. } & Pre test & 22 & 27,433 & 7,679 & 15,53 & 42,54 \\
S.L.J. & Final test & & 22,39 & 6,707 & 13,33 & 35,27 \\
& Pre test & 22 & 149,545 & 35,103 & 27 & 80 \\
FLEXIBILITYY & Final test & & 147,909 & 35,356 & 27 & 80 \\
& Pre test & 22 & 28,227 & 6,689 & 21 & 43 \\
30.M RUN & Final test & & 27,681 & 7,742 & 19 & 45 \\
& Pre test & 22 & 6,035 & 0,837 & 4,7 & 7,2 \\
SHUTTLE & Final test & & 6,236 & 0,915 & 4,72 & 7,5 \\
& Pre test & 22 & 37,363 & 21,816 & 12 & 74 \\
& Final test & & 34,857 & 20,060 & 10 & 71 \\
\hline
\end{tabular}

Table 9. Comparison of Pre- and Post- exercises Motoric Test Results of Control Group the Attending to the Research

\begin{tabular}{lccccc}
\hline \multicolumn{1}{c}{ Measurements } & \multicolumn{1}{c}{ N } & & \multicolumn{1}{c}{ Ss } & \multicolumn{1}{c}{ Min } & Max. \\
\hline VO2max1-VO2max2 & 22 & 5,043 & 5,555 & $2,580^{* *}$ & 7,506 \\
S.L.J.1-S.L.J.2 & 22 & 1,636 & 6,083 & $-1,06$ & 4,333 \\
FLEX.1- FLEX.2 & 22 & 0,545 & 2,595 & $-0,605$ & 1,696 \\
30 M.RUN.1-30M.RUN.2 & 22 & $-0,206$ & 0,224 & $-0,308$ & $-0,104$ \\
SHUTTLE 1- SHUTTLE 2 & 22 & 2,545 & 5,058 & 0,302 & 4,788
\end{tabular}

The data given in Tables 8 and 9 are statistical information of the pre-exercises and post- exercises motoric scores for

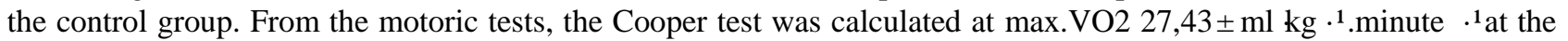

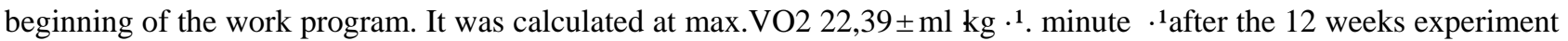
programme. In the Standing Long Jump test, a mean length of 149,545 $\pm \mathrm{cm}$ was taken at the beginning of the study program, but this value decreased to $147,909 \pm \mathrm{cm}$ after the exercises. At the beginning, the flexibility was $28,227 \pm \mathrm{cm}$, whereas at the end of the exercises program it decreased to 27,681 \pm . As to the 30-Meter Running Test, it was determined that the mean of the group was 6,035 \pm seconds at the beginning of the program and was 6,236 \pm seconds at the end of the program. At the beginning of the program, the average number of shuttles was 37,363 \pm , which was found to be $34,857 \pm$ shuttle at the end of the exercises program. From these values, there was a decrease in max VO2, long jump, $30 \mathrm{~m}$ running, flexibility and shuttle test results. Only the decrease in max VO2 from these data obtained from the control group was statistically significant $(\mathrm{p}<0,001)$.

\section{Discussion and Conclusion}

Folk dances are used as a very important means to reveal the feelings and thoughts inherent in individuals and societies in terms of historical development with their movement activities and at the same time to develop a spirit of unity because of being a social entity. Folk dances, Depending on the various movement figures applied and the time and the application form, the various durations and rhythms of these figures, can create physiological, biochemical and biomotoric changes as a result of a certain load on the human organism. In our survey, it was aimed to investigate some biomotorological, physiological and biochemical characteristics of folk dances on the beginner students from Yüzüncü Yil University Folk Dances. Therefore, at the beginning and at the end of the twelwe-week exercise program, some of the social characteristics, some biochemical characteristics such as LDH, CK, Cholesterol, Triglyceride, HDL, LDL and VLDL, and Biomorphological characteristics such as Durability, Flexibility, Force and Speed, of the folk dancers were observed.

In the study; Some data were obtained from biochemical analyzes at the beginning and at the end of the twelwe-week folk dances program. From these values, the LDH values taken from the subject group were calculated as $321,818 \pm$ at the beginning of the exercises program, while resting, but it decreased to 265,136 \pm at the end of the exercises program, while resting. Cretin kinas (CK) values were found as 169,772 \pm , while resting, at the beginning of the exercises program, but it decreased to $113,227 \pm$ at the end of the exercises program. For the control group, the LDH values were $238,636 \pm$, while resting, at the beginning of the exercises program, and was 249,590 \pm , while resting, at the end of the exercises program, and the CK values were 144,545 \pm , while resting, at the beginning of the exercises program and was $149,636 \pm$ at the end of the exercises program.

In our Survey, the biochemical data obtained from the experimental group after exercise was 372,136 \pm at the beginning of the study program and decreased to $290,409 \pm$ at the end of twelwe weeks of exercise program again after the daily exercise. CK and LDH are essential in terms of energy production in muscles. These enzymes are found in the cell. The presence of these enzymes in the blood indicates that the muscle cell membrane has suffered some damage. Following 
heavy training periods, it has been reported that the levels of these enzymes in the blood are two to ten times higher (Wilmore, 2004). Stupka et al. (2001) found that serum CK levels increased in blood samples taken twenty-four hours after exercise. In this study, females had lower serum cretin kinas (CK) activity than males. marathon runners shown remarkable damage after training and competition in their leg muscles and experienced marathoner claimed this was accompanied by a pain. However, the effects of muscle damage on performance are not yet fully understood. Researchers suspect that this damages to the muscles is caused by exercises that mostly occur with eccentric contractions (Wilmore, 2004). It has been reported that acute peroxidative environment resulting from oxidative stress resulting from exercise is increased due to muscular damage caused by muscle cells, a decrease in the amount of serum lipid fat (Akgün 1986). Gencer et al. (2018) due to regular exhaustion and CK (Aslan, 1997).

At the end of the twelwe-week folk dance training program, the HDL value for the subject group was 44,690 \pm , while resting, at the beginning of the study program and was $62,490 \pm$, while resting, at the end of the study program. Triglyceride values decreased from 116,636 \pm , while resting, at the beginning of the study program to $61,105 \pm$, while resting, at the end of the study program. In our study, the HDL values for the subject group from biochemical data obtained immediately after exercise increased from 44,238 \pm at the beginning of the study program to $61,181 \pm$ after exercise at the end of the study program. Triglyceride values decreased from $88.5 \pm$ at the beginning of the study program to $52,731 \pm$ after exercise at the end of the study program. Within the same time period, the HDL values of the control group rose to 55,872 \pm at rest at the beginning of the study program to $57,572 \pm$ at the end of the study program. Triglyceride values were found to be 114,409 \pm , while resting, at the beginning of the study program and 108,227 \pm , while resting, at the end of the study program. LeMura et al. (2000) found that in a sixteen-week study of sedentary and healthy subjects using three different types of exercise programs (aerobic training, strength training and mixed), the blood triglyceride concentrations of the aerobic training group significantly decreased and their HDL level significantly increased due to the training. In the same study, the relationship between decreasing in the body fat and increasing in the HDL levels was found to be significant. In addition, it was determined that the relationship between the increase of maximal oxygen consumption or aerobic capacity increase of HDL was also significant. LeMura et al. (2000) found that maximal VO2 increased by $25 \%$ and body fat decreased by $13 \%$ for previously sedentary individuals who have aerobic exercise for sixteen weeks.

Lipids are found abundantly as an oxidative fuel source in muscle contraction; and low triglyceride stores in the body can last for several days. An increased use of fat in the aerobic exercise will protect the muscular glycogen deposits which are limited, and this reservoir may be an advantageous source of severe exercise as a valuable reserve source (Selçuk 2006). A sedentary lifestyle can cause adverse changes in blood lipids. Regular exercises have been shown to increase HDL cholesterol, an arteriosclerosis barrier that reduces LDL cholesterol, which facilitates the formation of arteriosclerosis (Karacan, 2003). Stein et al. (1990) found a significant increase in blood HDL and a decrease in LDL level after 12-week cycling exercise. Studies have shown that physical exercises change plasma lipid and lipoprotein concentrations. Chronic aerobic exercises reduce LDL cholesterol and triglyceride levels when raising HDL cholesterol (Farrel and Barboriak, 1981, Enger et al., 1980). In his study Tamer (1996) was found that cholesterol reduced from 147.5 to 136.6 , triglyceride from 142.8 to 101.1 , while HDL increased from 48 vto 49 , as a result of run for the same distance but in different type. Grandjean et al. (2000) found out that, for hyper cholesterolemic (HC) and normo colestremic subjects, a reduction in triglycerides, decrease in high-density lipoprotein (HDL) 24 hours after exercise and HDL remained high until 48 after exercise. In an experimental study conducted by Tamer (1996), it was found that lipid and lipoprotein levels decreased with moderate aerobic exercises, and HDL cholesterol concentration increased and triglycerides, cholesterol, and LDL cholesterol concentration decreased, depending on the endurance training.

Studies have shown that Exercise causes a 6.3 percent decrease in Total Cholesterol, a $10.1 \%$ decrease in LDL cholesterol, and a 5\% increase in HDL Cholesterol. (www.anakarder.com/anadolu cardiology journal).

From the data obtained form our survey, it has been determined that the regular folk dance exercises lead to an increase in HDL level, a decrease in LDL, VLDL, cholesterol and triglyceride levels. The results we have found are consistent with the literature. Following our study of twelwe-week folk dances, we found that the maximal oxygen use capacity of the subject group, at the beginning of the study program increased from $39,902 \pm \mathrm{ml} \cdot \mathrm{kg} \cdot{ }^{1}$. minute ${ }^{1}$ to $42,132 \pm \mathrm{ml} \cdot \mathrm{kg} \cdot{ }^{1}$. minute $\cdot 1$, at the end of the programme, For the control group, the maximal oxygen utilization capacity was at $27,433 \pm$ $\mathrm{ml} \cdot \mathrm{kg} \cdot{ }^{1}$. minute $\cdot^{1}$ level at the beginning of the study program, but fell to $22,390 \pm \mathrm{ml} \cdot \mathrm{kg} \cdot{ }^{1}$. minute ${ }^{1}$ level at the end of the survey. Ruby et al. (1996), eighteen women aged between eighteen and twenty-five who had not been trained had jogging, cycling and mixed (running / cycling exercises. These studies were performed for ten weeks, four days a week at $70-80 \%$ of the number of reserve heartbeats. Max VO2 values of the subjects before exercise were determined in cycling ergometer. As a result of this study, it was stated that cycling, running and mixed exercises caused an increase in maximal oxygen consumption capacity of the subjects, and a reduction in the sub maximal heart rate at the 10th week for subjects whole running bicycle and mixed exercises. Utter et al. (2000); Turgut el all, (2017) reported a 9\% increase 
in the Max VO2 values of the results of the aerobic training program on a twelwe-week sub maximal level exercises. Blake et al. (2000) conducted a 14-week exercise on normal body weight subjects and found that MaxVO2 showed positive changes in endurance and flexibility values. There is an increase in total blood volume and haemoglobin count after exercise. Total blood volume and haemoglobin levels play an important role in the oxygen delivery system because both are closely related to the maximal oxygen utilization capacity (Fox, 1988). Aerobic capacity can be improved by endurance training. A sedentary person can improve his aerobic capacity by $15-20 \%$ by doing thirty minutes per week for three to six months for $75 \%$ of his capacity. An aerobic power can be increased to $42 \mathrm{ml} \cdot \mathrm{kg}-1 \mathrm{~min}-1$ with such a program, initially at $35 \mathrm{ml} \bullet \mathrm{kg}-1 \mathrm{~min} 1$ (Willmore, 2004).

When the literature is examined, it is seen that chronic aerobic exercises contribute to the development of biomotoric properties, increase the metabolic enzyme level, increase the number of intracellular capillaries, increase the number of mitochondria, and change the structure and activities of the respiratory and circulatory system. We can say that all of these changes will contribute positively to the exercise capacity of people who utilizing oxygen. When we look at the difference between the pre-test and post-test averages of the oxygen utilization capacity of the subject group in our study, we found a statistically significant difference. The result that the maximal oxygen utilization capacity of the control group did not change significantly between the start and end of the exercises was not statistically significant. The results we have found generally show that the regular folk dance exercises in the aerobic category affects the subject's maximal oxygen use capacity positively.

In our study, a sit and reach test was applied to the subject group in order to measure the flexibility feature. At the beginning of the study program, the subjects' flexibility averages were found to be $30,09 \pm \mathrm{cm}$, and at the end of the study program it increased to $33,36 \pm \mathrm{cm}$. In the sit-in test conducted for the control group, it was determined that the flexibility average was $28,227 \pm \mathrm{cm}$ at the beginning of the study program and decreased to $27,681 \pm \mathrm{cm}$ at the end of the study program. Kin (1996); Atli et al (2011). Sarikaya et al, (2016) measured the flexibility of subjects with forty-eight weeks of step-aerobic and aerobic-dance practice for forty-eight girls. At the end of the survey, the Sit-Eris test of the Step-Aerobic group was found to be $2.44 \mathrm{~cm}$ and the increase in the Aerobic-Dance group was $1.28 \mathrm{~cm}$. Zorba et al. (2000); Sarikaya et al, (2016) applied a high grade step exercises or forty-five minutes and three days in a week during eight weeks and found a positive increase in flexibility values after training. Flexibility has been an important contributor to biomaterials. The goodness of this feature is a positive contribution to the increase in muscle strength, the increase in the rate of contraction, recovery after exercise, and the prevention of disability.

When the control group's flexibility averages were compared to the subject group, the difference between the flexibility characteristics of the participants in the folk dances was clearly evident. In our study, it was determined that there was no significant change in the control group in which the flexibility characteristics of the folk dance group increased when the control group's flexibility averages were compared with the folk dance group. According to these results, we can say that the exercises of folk dances is a positive effect on the development of flexibility. We can say that the folk dance exercises may cause positive changes in the muscles as a form of exercise, but the stretching exercises made during the warming phase and at the cooling stage at the beginning of the studies have contributed positively to this difference. As a form of exercise, it is possible to say that Folk Dance alone makes this difference but it can be said by giving more detailed works.

During the twelve-week folk dances, a standing long jump test was performed to determine the leg strength of the subjects. At the beginning of the exercise program, the average of the participants was $174,00 \pm \mathrm{cm}$ while the standing long jump average was $177,55 \pm \mathrm{cm}$ at the end of the exercise program. For the control group, at the beginning and end of the twelve-week exercise, the long jump average was $149,545 \pm \mathrm{cm}$ at the start of the exercise program and 147,909 $\pm \mathrm{cm}$ after the exercise. According to these results obtained from our work, we can say that folk dance studies have contributed positively to the development of strength from the biomotoric characteristics. The averages of the data obtained are statistically significant. The figures in the Folk Dance are made up of walking, bouncing, and sometimes moving groups at speed close to the running form. However, the bounce group exercises in the dance are mostly used for the general characteristic of the games. These exercises using body weight will contribute to a general strength development.

In our study, the Shuttle Test was performed to determine the abdominal stamina. At the beginning of the exercise program, the average number of shuttles for the subject group was 49,860 \pm , whereas it was found to be $56,550 \pm$ after the exercise program. In the control group, the average number of shuttles at the beginning of the exercise program was $37,363 \pm$ and the average number of shuttles at the end of the exercise program was 34,857 \pm . Kin (1996) found that at the end of the twelve-week Aerobic Dance exercise, the subject group showed an increase of 4.07 in the shuttle test results and a decrease of 0.81 in the control group. Basic (2001) was found that the number of shuttles increased by an average of 29,10 after increasing the number of shuttles to 25,80 at the beginning of the exercise of strength and endurance training for students aged 15-18 years. The results from our twelve-week exercise programe are consistent with the literature reviewed. 
Almost all of the data we obtained at the end of the Folk Dance exercise we applied regularly for twelve weeks gave positive results. Regular Folk Dance exercises resulted in similar to the positive results achieved with other aerobic exercises. We believe that regular folk dance activities may cause a positive social change in the physical form and health and may cause positive changes in the biomotoric and biochemical characteristics of those involved in such activities and may affect them positively.

\section{Referenses}

Aldemir, H. (199). The Effect of Exercise Chronobiology on hematological, biochemical, heamodynamic and cardiovascular parameters and oxidative. Gazi University Health Sciences Institute, Ankara,

Aslan, R. (1997). Investigation of the Effects of Acute and Programmed Submaximal Exercises on Lipid Peroxidation and Antioxidant Defense System of Erythrocyte Membrane in Sedanter, Yüzüncü Yıl Üniversity, Healty Sciences Institute, Biochemistry Anabilim Dalt.

Atli, M., Temur, H. B., Gencer, G., \& Şensoy N. (2011). The Comparison of Biometric Characteristics of Yüzüncü Yıl University Tennis Team Players to Sedentary People. Yüzüncü Yıl University Journal of Education Faculty. Special Volume: 175-181.

Ay, G. F. (Halkbilim), Pan Publishing, İstanbul, 1999.

Baumgartner, T. A., Jackson, A. S., Mahar, M. T., \& Rowe, D. A. (2003). Measurement for Evaluation in Physical Education and Exercise Science, Seventh Edition, McGraw-Hill, Newyork,

Blake, A., Miller, W. C., \& Brown, D. A. (2000). Adiposity does not hinder the fitness response to exercise training in obese women. J. Sports Med. Phys. Fitness, 40, 107-177.

Diker, G., \& Müniroğlu, S. (2016). Investıgatıon Of Physıcal Features Of Young Players Who Are Between 8-14 Accordıng To Age i. Ankara Üniversity Sports Science Faculty, 14(1), 45-52.

Enger, S. C., Stromme, S. R., \& Refsum, H. E. (1980). High density lipoprotein cholesterol, total cholesterol and trigllserides in serum after a single exposure to prolonged heavy exercise. Scand J Clin Lab Invest, 40, $341-345$. https://doi.org/10.3109/00365518009092653

Farrel, P. A., \& Barboriak, J. (1981). The time cours of alterations in plasma lipids in lipoprotein concentrations during eight weeks of endurance training. Atherosclerosis, 37, 231-238. https://doi.org/10.1016/0021-9150(80)90008-8

Fox, E. L., Bowers, R. W., \& Foss, M. L. (1998). The Physiological Basis of Physcial Education, 4 nd Ed. W.B Saunders Company, Printed in the U.S.A.

Grandjean, P. W., Crouse, S. F., \& Rohack, J. J. (2000). Influence of cholesterol status on blood lipid and lipoprotein enzyme responses to aerobic exercise, J. Appl. Physiol, 89(2), 472-480. https://doi.org/10.1152/jappl.2000.89.2.472

Karacan, S., \& Çolakoğlu, F. F. (2003). The Effects Of Aerobic Exercise On The Body Composition And Blood Lipids In Middle Aged And Young Women. Spormetre Phsical Education and Sports Science Journal, I(2), 83-88.

Kin, A., Koşar, N., \& Tuncel, F. (1996). Comparıson Of The Effects Of 8 Weeks Of Step Aerobics And Aerobic Dancing On Physical Fitness Of Female Unıversity Students. Hacattepe University Sports Science Journal, 7(3), 21-31.

Koç H., Pulur, A., \& Karabulut, E. O. (2011). Comparison Of Some Motor Abilities Of Male Basketball And Handball Players. Phsical Educaiton and Sports Science Jornal, 5(1), 21-27.

Lemura, L. M., \& Amdreacci, J. (2000). Lipit and Lipoprotein Profiles, Cardiovascular Fitness, Body Composition and Diet During and After Resistance, Aerobic and Combination Training in Young Woman, Eur. Journal Appl. Physiology, 82, 5-6. https://doi.org/10.1007/s004210000234

Orhun, A. (1998). Sport, Aesthetic And Aesthetic Education. Phsical Education and Sports Science Journal, III(4), 43-52.

Ruby, B., Robergs, R., Leadbetter, G., Mermier, C., Chick, T., \& Stark, D. (1996). Cross-training between cycling and running in untrained females, J. Sports Med. Phys. Fitness, 36(4), 246-254.

Sarikaya, M., Cinar, V., \& Selcuk, M. (2016). Examination on the effect of the training program implemented during preparation period on the physical characteristics of tennis players. International Journal of Sport Studies, 6(10).

Sarikaya, M., Cinar, V., \& Selcuk, M. (2016).Examination on the Effect of the preparation Period Trainings on the Physical Fitness Characteristics of Female Tennis Players. Annals of "Dunarea de Jos" University of Galati-Fascicle XV: Physical Education and Sport Management. Galati University Press. Volume: 2. Romania. 
Saygin, Ö., Polat, Y., \& Karacabey, K. (2005). The Effects Of Movement Training, Applied To Children On Their Physical Fitness Parameters. Firat University Healty Science Medicine Journal.19, $205-212$.

Selçuk, M. (2003). The Effect of programmed aerobic and anaerobic exercise on some antioxidant sedantery and sportmen doing Nordic discipline. Yüzüncü Yil University, Healty Science Institute.

Selçuk, Ö. (2006). Investigation of the Effects of 12 Week Endurance Training at 1700 Meters Height on Some Blood Parameters of Skiers. Yüzüncü Yll University, Healty Sciences Institute, Phsical Education and Sport Eğitimi ve Sports Anabilim Dall.

Stein, R. A., Michielli, D. W., Glantz, M. D., Sardy, H., Cohen, A., Goldberg, N., \& Brown, C. D. (1990). Effects of different exercise training intensities on lipoprotein cholesterol fractions in healthy middle-aged men. American Heart Journal. 119(2): 277-283. https://doi.org/10.1016/S0002-8703(05)80017-1

Stupka, N., Tarnopolsky, M. A., Yardley, N. J., \& Phillips, S. M. (2001). Cellular adaptation to repeated eccentric exercise-induced muscle damage. Journal of Applied Physiology, 91(4), 1669-1678. https://doi.org/10.1152/jappl.2001.91.4.1669

Taşkın, C., Karakoç, Ö., Nacaroglu, E., \& Budak, C. (2015). An Investigation of the Relationship Between Selected Motoric Features in Footballer Children. Sports and Performance Researchs Journal, 6(2), 101-107.

Temel, Y. (2001). Impact of VO2 Max Consumption and Local Durability in Male Students for 15-18 Age Group of Strength and Endurance Trainings. Kütahya: Dumlupınar Üniversity, Social Sciences İnstitute, Physical Education and Sport Anabilim Dall.

Turgut, M., Çınar, V., Akbulut, T., \& Kılıç, Y. (2017). EFFECT OF ACUTE EXERCISE ON LIPID LEVELS OF WOMAN. European Journal of Physical Education and Sport Science.

Utter, A. C., Whitcomb, D. C., Nieman, D. C., Butterworth, D. E., \& Vermillion, S. S. (2000). Effects of exercise Training on gallbladder function in An obese female population, Medicine and Science In Sprts and Exercise, 32(1), 41-45. https://doi.org/10.1097/00005768-200001000-00007

Wilmore, J. H., \& Costill, D. L. (2004). Physiology of Sport and Exercise, Third Edition. Human Kinetics, Printed in Hong Kong,

Yoncalık, O. (2004). Folk Dances And Physical Education Teaching As A Cultural Transfer Area In The National Education. Milli education Journal, 164.

Zorba, E., Yaman, R., Yıldırım, S., \& Saygın, Ö. (2000). The Effect of Weekly Stepping Practice on Some Physical Fitness and Anthropometric Values in 18-24 Age Group Sedanter Female Students, 1. Gazi Phyiscal Education and Sport Sciences Congress Ankara.

\section{Copyrights}

Copyright for this article is retained by the author(s), with first publication rights granted to the journal.

This is an open-access article distributed under the terms and conditions of the Creative Commons Attribution license which permits unrestricted use, distribution, and reproduction in any medium, provided the original work is properly cited. 